\title{
Development and Organoleptic Evaluation of Sweet Biscuits Formulated By Using Wheat Flour, Barley Flour and Germinated Fenugreek Seed Powder for Diabetics
}

\author{
Himani Lalit* and Anita Kochhar \\ Department of Food and Nutrition, Punjab Agricultural University, India
}

Submission: November 23, 2017; Published: March 09, 2018

*Corresponding author: Himani Lalit, Department of Food and Nutrition, Punjab Agricultural University, Ludhiana-141001, Punjab, India, Email: arora.lalit93@gmail.com

\section{Abstract}

Sweet biscuits were developed using wheat flour, barley flour and germinated fenugreek seed powder. Organoleptic evaluation was done and found highly acceptable at different levels. Incorporation of barley flour and germinated fenugreek seed powder was highly acceptable at 20 and 2 percent level. The protein content was increased 5.8 percent. Fiber content was significantly increased 30.3 percent. Phytic acid content was decreased 3.3 percent. The products were popularized among the diabetics by visiting Dayan and Medical College and Hospital, Ludhiana on regular basis at interval of 15 days for 3 months. The developed bakery products could be recommended for nutritional and health benefits because they are cost effective, nutritious and helps to manage different diseases.

\section{Introduction}

After China, the world's second highest manufacturer of food is India and has the potential to become greatest market among the convenient food sector. Excess of fast food consumption and less of fruits, vegetables and dairy products are frequently seen in adolescents [1]. When the pancreas does not produce enough insulin or when the body cannot effectively use the insulin it produces, leads to the diabetes. The most relished bakery product by consumer all over the world is cake and involves sugar as the basic ingredient. The baking industry, now these days very much trend in prepared products like high protein, low calorie and high fiber etc. Mixing of whole grains which contain rich sources of protein, dietary fiber and minerals in staple foods are considered good for health [2]. Barley is a richest source of dietary fiber contains both soluble in the form of $\beta$-glucan and insoluble fiber [3]. Regular consumption of barley helps in reducing cholesterol and maintaining blood sugar levels. Fenugreek seeds, from the legume family, contain great nutritive value and since the ancient times has been consumed as a whole seed. It is known for its medicinal qualities such as antidiabetic, anticarcinogenic, hypocholesterolemic, antioxidant, and immunological activities. Fenugreek seeds have good amount of iron (21mg/100g), calcium (182mg/100g), zinc $(4.9 \mathrm{mg} / 100 \mathrm{~g})$ and many more constituents. Sprouting improves in vitro protein digestion, as well as fat absorbing power and the extent of germination determines the actual composition [4]. Hence, development of such therapeutic bakery products would help to raise the nutritional status of population.

\section{Material and Methods}

\section{Procurement and processing of raw materials}

The fenugreek seeds Kasuri Supreme, were obtained from the Department of Vegetable Science and wheat (PBW550) were procured from Department of plant Breeding and Genetics, Punjab Agricultural University, Ludhiana. Barley flour and other ingredients like wheat flour, barley flour, oil, ghee, butter, salt, yeast, sugar, baking powder and baking soda were purchased from the local market of Ludhiana.

\section{Processing of fenugreek seeds}

Soaking: Fenugreek seeds were cleaned and free from the broken seeds, dust and other foreign materials and then soaked in tap water for $12 \mathrm{~h}$ at $37^{\circ} \mathrm{C}$. 
Germination: The soaked seeds were allowed to germinate in muslin cloth tied loosely for $48 \mathrm{~h}$ in incubator at $37^{\circ} \mathrm{C}$ with frequent watering. The sprouts were rinsed in distilled water and dried at $55-60{ }^{\circ} \mathrm{C}$. The dried samples of raw and germinated seeds were ground to fine powder in an electric grinder and packed in zip lock bags and then stored in plastic containers for further use.

\section{Development and standardization of barley flour and germinated fenugreek seed powder based sweet biscuits}

Table 1: Sweet Biscuits were standardized at two levels.

\begin{tabular}{|c|c|c|c|c|c|}
\hline Sweet Biscuits & \multicolumn{5}{|c|}{ Amount(g) } \\
\hline \multicolumn{7}{|c|}{ Standardization-I } \\
\hline & Control & E1 & E2 & E3 & E4 \\
\hline Wheat flour & 100 & 95 & 90 & 85 & 80 \\
\hline Barley flour & - & 5 & 10 & 15 & 20 \\
\hline \multicolumn{7}{|c|}{ Standardization-II } \\
\hline Control & F1 & F2 & F3 & F4 \\
\hline Wheat flour & 80 & 79 & 78.5 & 78 & 77.5 \\
\hline Barley flour & 20 & 20 & 20 & 20 & 20 \\
\hline $\begin{array}{c}\text { Germinated fenugreek } \\
\text { seed powder }\end{array}$ & - & 1 & 1.5 & 2 & 2.5 \\
\hline
\end{tabular}

Sweet biscuits were prepared by using standardized recipe with barley flour and germinated fenugreek seed powder at different levels shown in Table 1.

\section{Preparation of sweet biscuits}

Ingredients:

Wheat flour $\quad$ - $\quad 78 \mathrm{~g}$

Barley flour $\quad$ - $\quad 20 \mathrm{~g}$

Germinated fenugreek $\quad-\quad 2 \mathrm{~g}$

Seed powder

Powdered sugar

Fat (butter) $\quad$ - $\quad 45 \mathrm{~g}$

Water $\quad-\quad 7 \mathrm{ml}$
Baking powder

$1 \mathrm{~g}$

\section{Method}

1. Fat was rubbed on a clean surface.

2. Flours were sifted and baking powder was added gradually.

3. Sugar was added in it.

4. Smooth dough was made by using water.

5. Dough was rolled to $1 / 4$ inch thickness.

6. Round shapes were cut and baked at $150{ }^{\circ} \mathrm{C}$ for 20 minutes.

Total weight - $168 \mathrm{~g}$

No. of servings - 14

Weight per serving - $12 \mathrm{~g}$

Sensory characteristics: Sweet biscuits were organoleptically evaluated by a semi-trained panel of 10 judges from Department of Food and Nutrition, College of Home Science, Punjab Agricultural University, as well as from 15 diabetics from Dayanand Medical College and Hospital, ludhiana. The judges were served each preparation with one control and eight experimental samples. The samples were coded to avoid any biased judgement. Judges were asked to score the samples for appearance, colour, texture, flavour, taste and overall acceptability using a score card of 9-point Hedonic Rating Scale by [5].

\section{Nutritional analysis}

Proximate composition: Proximate composition will be estimated by employing standard methods of analysis by [6].

Antinutritional factors: Phytic acid was estimated by Haug and Lantzsch and Total polyphenols by [7].

Statistical analysis: The data was analysed with the help of statistical tool such as mean score. To test the significant difference between the control and experimental samples kruskal Wallis Test and one way ANOVA was applied using SPSS 16 software.

\section{Results and Discussion}

\section{Organoleptic evaluation}

Table 2: Mean sensory scores for sweet biscuits incorporated with barley flour.

\begin{tabular}{|c|c|c|c|c|c|c|}
\hline \multirow{2}{*}{ Proportions } & \multicolumn{6}{|c|}{ Parameters } \\
\hline & Appearance & Colour & Texture & Flavour & Taste & Overall Acceptability \\
\hline \multicolumn{7}{|c|}{ WB (wheat + barley flour) } \\
\hline $\mathrm{C}$ & 7.3 & 7.3 & 7.5 & 7.6 & 7.6 & 7.5 \\
\hline E1 & 7.4 & 7.45 & 7.6 & 7.65 & 7.5 & 7.52 \\
\hline E2 & 7.2 & 7.2 & 7.35 & 7.25 & 7.25 & 7.25 \\
\hline E3 & 7.7 & 7.7 & 7.5 & 7.5 & 7.5 & 7.58 \\
\hline
\end{tabular}




\section{Current Research in Diabetes \& Obesity Journal}

\begin{tabular}{|c|c|c|c|c|c|c|}
\hline E4 & 7.9 & 7.9 & 7.9 & 7.8 & 7.8 & 7.86 \\
\hline$\chi^{2}$ & $7.132^{\mathrm{NS}}$ & $7.005^{\mathrm{NS}}$ & $4.977^{\mathrm{NS}}$ & $3.255^{\mathrm{NS}}$ & $3.557^{\mathrm{NS}}$ & \multicolumn{2}{c|}{$5.126^{\mathrm{NS}}$} \\
\hline \multicolumn{7}{|c|}{ WBGF(wheat +barley flour + germinated fenugreek seed powder } \\
\hline C & 7.3 & 7.3 & 7.4 & 7.8 & 7.9 & 7.54 \\
\hline F1 & 7.4 & 7.4 & 7.5 & 7.6 & 7.6 & 7.5 \\
\hline F2 & 7.3 & 7.3 & 7.4 & 7.2 & 7 & 7.26 \\
\hline F3 & 7.6 & 7.5 & 7.1 & 7.6 & 7.6 & 6.74 \\
\hline F4 & 7.1 & 7.1 & 7 & 6.4 & 6.3 & $19.498^{*}$ \\
\hline$\chi^{2}$ & $10.234^{*}$ & $9.798^{*}$ & $10.680^{*}$ & $23.286^{*}$ & $25.135^{*}$ & \\
\hline
\end{tabular}

*Significant at $5 \%$ level of significance $(p<0.05)$. NS- Non-significant

C -Control (100\% wheat flour), E1- 10\%, E2- 15\%, E3- 20\% and E4- 25\% Barley Flour

C- Control (75\% wheat flour $+25 \%$ barley flour), F1- 1\%, F2- 1.5\%, F3- $2 \%$ and F4- 2.5\% Germinated Fenugreek Seed Powder

WB: Whole wheat flour + barley flour

WBGF : whole wheat flour + barley flour + germinated fenugreek seed powder

Sweet biscuits were prepared using basic ingredient i.e. wheat flour for control samples and for test samples, wheat flour was supplemented with barley flour and germinated fenugreek seed powder at different levels s. The developed products were organoleptically evaluated by a semi-trained panel of 10 judges from the Department of Food and Nutrition as well as from15 diabetics from Dayanand Medical College and Hospital, Ludhiana by using 9 point hedonic rating scale to judge the acceptability of the products shown in Table 2 \& Figure 1.

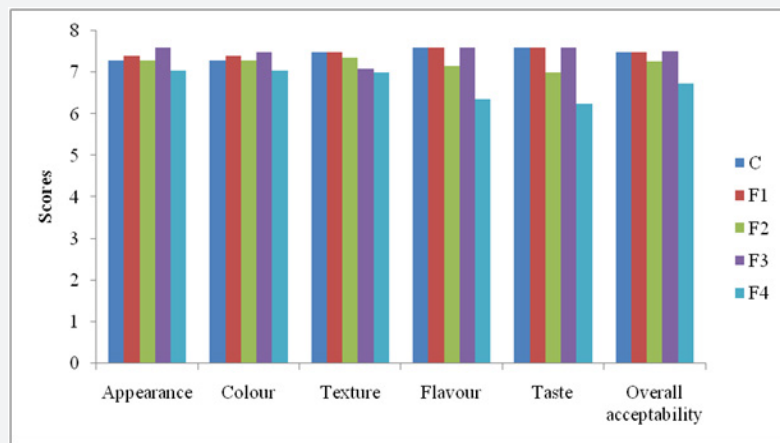

Figure 1: Mean sensory scores for sweet biscuits incorporated with barley flour and germinated fenugreek seed powder.

When sweet biscuits were supplemented with barley flour at different levels, the statistical analysis of the score it was observed that the overall acceptability of appearance, colour, texture, flavour and taste of E4 treatment were non-significantly higher i.e. 7.86 than that of control i.e. 7.5. When biscuits were supplemented with germinated fenugreek seed powder at different levels, the results revealed that the highest scores for all the sensory parameters among test samples were obtained by $\mathrm{F} 3$ treatment (2\%). Statistical results revealed that there was significant difference between the treatments and control sample among all the sensory parameters.

\section{Nutritional evaluation}

Proximate composition: The results revealed that the moisture content of control sample (whole wheat flour) was 19.78percent which was significantly higher than both E4 (80\% whole wheat flour and $20 \%$ germinated fenugreek seed powder) and F3 (78\% whole wheat flour, 20\% barley flour and $2 \%$ germinated fenugreek seed powder) treatments i.e. 19.5 and 19.49 per cent. Protein content was also significantly higher in F3 treatment (11.17\%) and E4 treatment (10.6\%) than the control sample (10.56\%). Fat content in control sample (18.96\%) was significantly higher than E4 treatment (18.93\%) and F3 treatment (18.89\%). Fiber content of E4 (2.27\%) and F3 $(2.45 \%)$ treatment was significantly increased than the control sample (1.88\%). Ash content of control sample (1.23\%) was significantly higher than the E4 treatment (1.18\%) but lower than F3 treatment (1.25\%). Carbohydrate content was observed in control sample and E4 treatment as $47.57 \mathrm{~g}$ and $47.93 \mathrm{~g}$ but significantly lower in F3 treatment i.e. $46.75 \mathrm{~g}$. Energy content of control sample, E4 treatment and F3 treatment had similar value with $403 \mathrm{Kcal}$. Thus it was observed that the supplementation of barley flour and germinated fenugreek seed powder in Sweet Biscuits increased the nutritional content as compared to the control Sweet Biscuits made from whole wheat flour only (Table 3).

Table 3: Proximate composition of sweet biscuits.

\begin{tabular}{|c|c|c|c|c|c|c|c|}
\hline Treatment & Moisture (\%) & Protein (\%) & Fat (\%) & Fiber (\%) & Ash (\%) & CHO (g) & Energy (Kcal) \\
\hline Control (W) & $19.78^{\mathrm{a}} \pm 0.005$ & $10.56^{\mathrm{c}} \pm 0.005$ & $18.96^{\mathrm{b}} \pm 0.005$ & $1.88^{\mathrm{c}} \pm 0.005$ & $1.23^{\mathrm{a}} \pm 0.005$ & 47.57 & 403 \\
\hline Accepted (E4) (WB) & $19.5^{\mathrm{b}} \pm 0.005$ & $10.6^{\mathrm{b}} \pm 0.005$ & $18.93^{\mathrm{a}} \pm 0.005$ & $2.27^{\mathrm{a}} \pm 0.005$ & $1.18^{\mathrm{c}} \pm 0.005$ & 47.93 & 403 \\
\hline Accepted (F3) (WBGF) & $19.49^{\mathrm{c}} \pm 0.005$ & $11.17^{\mathrm{a}} \pm 0.05$ & $18.89^{\mathrm{c}} \pm 0.005$ & $2.45^{\mathrm{b}} \pm 0.005$ & $1.25^{\mathrm{b}} \pm 0.008$ & 46.75 & 403 \\
\hline
\end{tabular}

Means with different notation ( $a, b$ and $c$ ) indicates significant difference at $5 \%$ level of significance

Control (W) - Whole wheat flour, Accepted (WB) - Whole wheat flour + barley flour and Accepted (WBGF) - whole wheat flour + barley flour + germinated fenugreek seed powder. 


\section{Phytic acid and polyphenol content}

The phytic acid content of sweet biscuits were found higher in control sample with $74.63 \mathrm{mg} / 100 \mathrm{~g}$, followed by E4 treatment with $74.23 \mathrm{mg} / 100 \mathrm{~g}$ than $72.16 \mathrm{mg} / 100 \mathrm{~g}$ in F3 treatment which was significantly lower. Phytic acid content decreased with the supplementation of germinated fenugreek seed powder. The polyphenol content get increased with the supplementation of barley and germinated fenugreek seed powder.

Means with different notation (a, b and c) indicates significant difference at $5 \%$ level of significance

Table 4: Anti-nutritional factor of value added bakery products.

\begin{tabular}{|c|c|c|}
\hline Treatment & $\begin{array}{c}\text { Phytic } \\
\text { Acid(mg/100g) }\end{array}$ & Total Polyphenols(mg/100g) \\
\hline Control (W) & $74.63^{\mathrm{b}} \pm 0.005$ & $214.7^{\mathrm{a}} \pm 0.005$ \\
\hline $\begin{array}{c}\text { Accepted (E4) } \\
\text { (WB) }\end{array}$ & $74.23^{\mathrm{a}} \pm 0.005$ & $204.14^{\mathrm{b}} \pm 0.005$ \\
\hline $\begin{array}{c}\text { Accepted (F3) } \\
\text { (WBGF) }\end{array}$ & $72.16^{\mathrm{c}} \pm 0.005$ & $215.67^{\mathrm{c}} \pm 0.005$ \\
\hline
\end{tabular}

Control (W) -Whole wheat flour, Accepted (WB) - Whole wheat flour + barley flour and Accepted (WBGF) - whole wheat flour + barley flour + germinated fenugreek seed powder (Table 4).

\section{Conclusion}

Incorporation of barley flour at 20 percent level and germinated fenugreek seed powder at 2 percent level was highly acceptable. Supplemented sweet biscuits showed increase in protein, fibre and energy. Phytic acid content was significantly decreased and polyphenol content got increased. Value added bakery products are recommended for nutritional and health benefits because they are cost effective, nutritious and helps to manage different diseases.

\section{References}

1. Gomathy R, John S (2008) Measuring psychosocial, environmental and behavioural factors that influence the fruit and vegetable intake of adolescent girls. J Ind Dietet Assoc 33(2): 26-37.

2. Indrani D, Swetha C, Soumya C, Jyotsna R, Rao G V (2011) Effect of multigrains on rheological, microstructural and quality characteristics of north Indian parotta-An Indian flat bread. LWT- Food Science and Technology 44(3): 719-724.

3. Bokulich NA, Bamforth C W (2013) The microbiology of malting and brewing. Microbiol Mol Biol Rev 77(2): 157-172.

4. Hooda SB, Jood S (2005) Organoleptic and nutritional evaluation of wheat biscuits supplemented with untreated and treated fenugreek flour. Food Chemistry 90(3): 427-435.

5. Larmond E (1970) Methods of sensory evaluation of food. Can Deptt Agric Pubs, pp. 1284-1290.

6. AOAC (2000) Official Method of Analysis Association of Official Analytical Chemist, (17 $7^{\text {th }}$ edn $)$, USA.

7. AOAC (1965) Official methods of analysis. Association of Official Analytical Chemists: USA.



